\title{
DAMPAK URBANISASI BAGI PERKEMBANGAN KOTA DI INDONESIA
}

\author{
Fitri Ramdhani Harahap, S.Sos., M.Si*
}

\begin{abstract}
This paper discusses the impact of urbanization posed by the rapidly developing city. Urbanization is the result of urban development and economic which ultimately affect the dynamics of the city, especially in contact with the city's ability as an attraction for people to work and live. The impact of urban development is first, physical: land vs land up green, the distribution of urban facilities, transportation networks, patterns of movement to the city center, the development of land use, environmental issues, and slums. Second, socially; unemployment, poverty, and criminalitas.
\end{abstract}

\section{Key words:}

Urbanization Impact, Developing City, and Urban Sociology

\section{PENDAHULUAN}

Maraknya pembangunan di kota-kota besar di Indonesia dapat memacu pertumbuhan ekonomi. Sebagai dampaknya, kota-kota tersebut akan menjadi magnet bagi penduduk untuk berdatangan mencari pekerjaan dan bertempat tinggal. Hal ini sering disebut dengan urbanisasi. Namun urbanisasi ini menimbulkan berbagai macam masalah karena tidak ada pengendalian di dalamnya. Masalah ini lah yang dihadapi Negara Indonesia saat ini yaitu pertumbuhan konsentrasi penduduk yang tinggi. Lebih buruk lagi, hal ini tidak diikuti dengan kecepatan yang sebanding dengan perkembangan industrialisasi. Masalah ini akhirnya menimbulkan fenomena yaitu urbanisasi berlebih.

Adanya urbanisasi yang berlebih ini telah menimbulkan berbagai masalah di Indonesia. Tidak hanya menimbulkan masalah di kota yang dituju namun juga menimbulkan masalah di desa yang

\footnotetext{
* Penulis adalah Dosen pada Jurusan Sosiologi, Fakultas Ilmu Sosial dan Ilmu Politik, Universitas Bangka Belitung.
}

ditinggalkan. Masalah yang terjadi kota antara lain yaitu meningkatnya angka kemiskinan sehingga pemukiman kumuhnya juga meningkat, peningkatan urban crime dan masih banyak masalah lain. Di desa juga akan timbul masalah diantaranya yakni berkurangnya sumber daya manusia karena penduduknya telah pergi ke kota, desa akhirnya tidak mengalami perkembangan yang nyata.

Urbanisasi dipicu adanya perbedaan pertumbuhan atau ketidakmerataan fasilitas-fasilitas dari pembangunan, khususnya antara daerah pedesaan dan perkotaan. Akibatnya, wilayah perkotaan menjadi magnet menarik bagi kaum urban untuk mencari pekerjaan. Dengan demikian, urbanisasi sejatinya merupakan suatu proses perubahan yang wajar dalam upaya meningkatkan kesejahteraan penduduk atau masyarakat. Perkembangan urbanisasi di Indonesia sendiri perlu diamati secara serius. Banyak studi memperlihatkan bahwa tingkat konsentrasi penduduk di kota-kota besar di Indonesia telah berkembang dengan pesat. Studi yang dilakukan oleh Warner Ruts tahun 1987 menunjukkan 
bahwa jumlah kota-kota kecil $(<100$ ribu penduduk) sangat besar dibandingkan dengan kota menengah (500 ribu sampai 1 juta penduduk). Kondisi ini mengakibatkan perpindahan penduduk menuju kota besar cenderung tidak terkendali. Ada fenomena kota-kota besar akan selalu tumbuh dan berkembang, kemudian membentuk kota yang disebut kota-kota metropolitan. Salah satu kota yang telah mengalami hal ini adalah kota Jakarta sebagai ibu kita dari negara Indonesia sendiri. Dimulai sebagai kota besar kemudian berkembang menjadi kota metropolitan dan saat ini mengarah menjadi kota megapolitan.

Kondisi perkotaan yang semakin tidak terkendali akibat adanya urbanisasi yang berlebih, telah menimbulkan berbagai masalah baru seperti meningkatnya kriminalitas akibat kemiskinan, pengangguran besar-besaran, bertambahnya pemukiman kumuh, dan lain sebagainya. Oleh karena itu, urbanisasi akan dlihat sebagai faktor penentu bagai sebuah kota dapat berkembang baik secara fisik, maupun secara sosial. Dengan begitu, bentuk atau pengertian dari urbanisasi itu dapat dilihat dengan lebih jelas juga akibat dampak yang ditimbulkannya terhadap kehidupan di kota.

\section{PEMBAHASAN}

\subsection{Pengertian Urbanisasi}

Pengertian urbanisasi menurut Ensiklopedi Nasional Indonesia adalah, suatu proses kenaikan proporsi jumlah penduduk yang tinggal di daerah perkotaan. Selain itu dalam ilmu lingkungan, urbanisasi dapat diartikan sebagai suatu proses pengkotaan suatu wilayah. Proses pengkotaan ini dapat diartikan dalam dua pengertian. Pengertian pertama, adalah merupakan suatu perubahan secara esensial unsur fisik dan sosial-ekonomi-budaya wilayah karena percepatan kemajuan ekonomi. Contohnya adalah daerah Cibinong dan Bontang yang berubah dari desa ke kota karena adanya kegiatan industri. Pengertian kedua adalah banyaknya penduduk yang pindah dari desa ke kota, karena adanya penarik di kota, misal kesempatan kerja.

Pengertian urbanisasi ini pun berbeda-beda, sesuai dengan interpretasi setiap orang yang berbeda-beda. Ir. Triatno Yudo Harjoko (2010) pengertian urbanisasi diartikan sebagai suatu proses perubahan masyarakat dan kawasan dalam suatu wilayah yang non-urban menjadi urban. Secara spasial, hal ini dikatakan sebagai suatu proses diferensiasi dan spesialisasi pemanfaatan ruang dimana lokasi tertentu menerima bagian pemukim dan fasilitas yang tidak proporsional.

Shogo kayono dalam Abbas (2002) memberikan pengertian urbanisasi sebagai perpindahan dan pemusatan penduduk secara nyata yang memberi dampak dalam hubungannya dengan masyarakat baru yang dilatar belakangi oleh faktor sosial, ekonomi, politik dan budaya. Sementara Keban dalam Abbas (2002) berpendapat bahwa urbanisasi jangan hanya dalam konteks demografi saja karena urbanisasi mengandung pengertian yang multidimensional. Urbanisasi dari pendekatan demografis berarti sebagai suatu proses peningkatan konsentrasi penduduk diperkotaan sehingga proporsi penduduk yang tinggal menjadi meningkat yang biasanya secara sederhana konsentrasi tersebut diukur dari proporsi penduduk yang tinggal di perkotaan, kecepatan perubahan proporsi tersebut, dan perubahan jumlah pusat-pusat kota. Sedangkan urbanisasi menurut pendekatan ekonomi 
politik didefenisikan sebagai transformasi sosial ekonomi yang timbul sebagai akibat dari pengembangan dan ekspansi kapitalisme (capitalist urbanization). Dalam konteks modernisasi, urbanisasi mengandung pengertian sebagai perubahan nilai dari orientasi tradisional ke orientasi modern sehingga terjadi difusi modal, teknologi, nilai-nilai, pengelolaan kelembagaan dan orientasi dari masyarakat tradisional ke dunia barat (kota).

Pengertian lain dari urbanisasi, dikemukakan oleh Dr. PJM Nas (2010), pengertian pertama diutarakan bahwa urbanisasi merupakan suatu proses pembentukan kota, suatu proses yang digerakkan oleh perubahan struktural dalam masyarakat sehingga daerah-daerah yang dulu merupakan daerah pedesaan dengan struktur mata pencaharian yang agraris maupun sifat kehidupan masyarakatnya lambat laun atau melalui proses yang mendadak memperoleh sifat kehidupan kota. Pengertian kedua dari urbanisasi adalah, bahwa urbanisasi menyangkut adanya gejala perluasan pengaruh kota ke pedesaan yang dilihat dari sudut morfologi, ekonomi, sosial dan psikologi.

Dari beberapa pengertian mengenai urbanisasi yang diuraikan di atas, maka dapat disimpulkan bahwa pengertian urbanisasi adalah merupakan suatu proses perubahan dari desa ke kota yang meliputi wilayah/daerah beserta masyarakat di dalamnya dan dipengaruhi oleh aspekaspek fisik atau morfologi, sosial, ekonomi, budaya, dan psikologi masyarakatnya.

\subsection{Dampak Urbanisasi}

Di Indonesia, persoalan urbanisasi sudah dimulai dengan digulirkannya beberapa kebijakan "gegabah" orde baru. Pertama, adanya kebijakan ekonomi makro
(1967-1980), di mana kota sebagai pusat ekonomi. Kedua, kombinasi antara kebijaksanaan substitusi impor dan investasi asing di sektor perpabrikan (manufacturing), yang justru memicu polarisasi pembangunan terpusat pada metropolitan Jakarta. Ketiga, penyebaran yang cepat dari proses mekanisasi sektor pertanian pada awal dasawarsa 1980-an, yang menyebabkan kaum muda dan para sarjana, enggan menggeluti dunia pertanian atau kembali ke daerah asal.

Arus urbansiasi yang tidak terkendali ini dianggap merusak strategi rencana pembangunan kota dan menghisap fasilitas perkotaan di luar kemampuan pengendalian pemerintah kota. Beberapa akibat negatif tersebut akan meningkat pada masalah kriminalitas yang bertambah dan turunnya tingkat kesejahteraan. Dampak negatif lainnnya yang muncul adalah terjadinya "over urbanisasi" yaitu dimana prosentase penduduk kota yang sangat besar yang tidak sesuai dengan perkembangan ekonomi negara. Selain itu juga dapat terjadi "under ruralisasi" yaitu jumlah penduduk di pedesaan terlalu kecil bagi tingkat dan cara produksi yang ada.

Pada saat kota mendominasi fungsi sosial, ekonomi, pendidikan dan hirarki urban. Hal ini menimbulkan terjadinya pengangguran dan under employment. Kota dipandang sebagai inefisien dan artificial proses "pseudo-urbanisastion". Sehingga urbanisasi merupakan variable dependen terhadap pertumbuhan ekonomi.

Persoalan-persoalan urbanisasi telah menjadi perhatian yang cukup besar, beberapa pemikiran yang membahas dampak urbanisasi dari sudut pandangn ekonomi yaitu Evers dalam Abbas (2002) berpendapat bahwa tingkat urbanisasi yang terlalu rendah dan mengabaikan kebutuhan- 
kebutuhan kota dapat memperlambat kemajuan ekonomi. Sedangkan menurut Keban, proses urbanisasi yang tidak terkendali dan adanya hirarki kota akan menimbulkan berbagai akibat negatif yaitu munculnya gejala kemiskinan di perkotaan, ketimpangan income perkapita, pengangguran, kriminalitas, polusi udara dan suara, pertumbuhan daerah kumuh, dan sebagainya.

Gmelch dan Zenner

membahas mengenai dampak sosial yang ditimbulkan oleh urbanisasi dengan menggunakan pendekatan tiga teori urbanisasi yaitu :

1. Determinist Theory atau dikenal juga dengan theory of urban anomie.

Writh (1938) sebagai salah satu tokoh yang paling berpengaruh dalam teori ini memulai analisasnya dengan mendefinisikan "kota" sebagai sebuah wilayah yang relatif besar, padat, dan tempat tinggal permanen dari individu yang secara sosial sangat beragam. Writh menganalisis bagaimana urbanisasi menghasilkan disorganisasi sosial dan gangguan kepribadian. Argumen yang digunakan Writh berdasarkan argument psikologi dan struktur sosial.

Argumen psikologi Writh didasarkan pada pemikiran George Simmel yang juga gurunya dalam tulisan "The Metropolis and Mental Life". Simmel memusatkan perhatiannya pada cara hidup di kota yang mengubah cara berfikir dan kepribadian individu. Bagaimana stimulasi yang cepat dan terputus dirubah oleh stimulasi yang datang dari dalam dan luar individu. Stimulasi yang paling berpengaruh menurut Simmel antara lain adalah pemandangan, suara, bau, tindakan orang lain, sehingga individu merespon untuk melindungi diri dan beradaptasi dengan fikiran dan hati. Dengan adanya stimulasi dan cara individu merespon tersebut menjadikan individu lebih intelek, rasional, dan berjarak secara emosional dengan orang lain. Suara klakson, telepon, pantulan cahaya, pandangan dan perilaku orang asing, berita surat kabar mempengaruhi perilaku individu dengan reaksi yang berbeda-beda. Hal ini sangat memungkinkan bagi individu untuk mengalami gangguan kepribadian.

Analisa struktur sosial dalam teori ini tidak jauh berbeda dengan argumen psikologi, tetapi dalam proses yang berbeda. Dalam kompetisi ekonomi, spesialisasi pekerjaan, meraih keunggulan, dan kemajemukan kota menghasilkan keberagaman aktivitas kehidupan sosial, seperti di dunia pekerjaan, kehidupan bertetangga, rumah tangga, dan sebagainya. Sehingga waktu dan perhatian inidividu terpecah dan terputus pada tempat dan orang yang berbeda. Sebagai contoh, seorang pengusaha; sarapan pagi dengan keluarga, rapat dengan rekan kerja di kantor, makan siang dengan kolega, rapat dengan klien, bermain golf dengan teman-teman, dan akhirnya makan malam dengan tetangga. Keberagaman aktivitas ini membuat inidividu terisolasi dari kehidupan sosialnya dan inilah yang memberi peluang terjadinya anomi karena hilangnya ikatan-ikatan sosial yang berisi nilai-nilai.

\section{Compositional theory.}

Tidak seperti Determinist Theory, teori ini menganggap bahwa urbanisasi tidak berdampak secara langsung terhadap 
individu atau masyarakat. Teori ini berpendapat bahwa keberagaman kehidupan sosial tidak serta merta mempengaruhi perilaku individu dan masyarakat sebab setiap individu atau masyarakat memiliki atribut-atribut yang dapat membantu mereka menangani permasalahan urbanisasi. Atribut-atribut yang dimaksud antara lain etnisitas, latar belakang keluarga, kehidupan bertetangga, kekerabatan, ikatan pekerjaan, dan lain-lain. Jadi tidak semua individu dapat terpengaruh oleh urbanisasi karena tergantung pada atribut-atribut yang dimilikinya. Sebagai contoh, seseorang yang tidak menikah bukan disebabkan oleh ketidak mampuan secara pribadi tetapi lebih dikarenakan oleh perbandingan antara laki-laki dan perempuan yang tidak seimbang.

3. Subculture theory.

Teori ini sebagai hasil sintesa dari Determinist Theory dan Compositional theory, melihat bahwa urbanisasi berdampak langsung terhadap individu dan masyarakat tetapi tidak mengintervensi. Asumsinya didasarkan pada pada dua hal yaitu; pertama, banyaknya migran yang datang ke kota dengan membawa budaya dan nilai yang beragam sehingga memberikan kontribusi terhadap bentuk keberagaman kehidupan sosial. Kedua, tekanan-tekanan struktur yang beragam seperti spesialisasi pekerjaan, tuntutan institusi, dan sebagainya yang menghasilkan subkultur-subkultur baru. Sebagai contoh subkultur mahasiswa, etnis Cina-Amerika, criminal professional, homoseksual, artis, misionaris, dan lain-lain.
Dampak negatif lainnya yang ditimbulkan oleh tingginya arus urbanisasi di Indonesia adalah sebagai berikut :

1. Semakin minimnya lahan kosong di daerah perkotaan. Pertambahan penduduk kota yang begitu pesat, sudah sulit diikuti kemampuan daya dukung kotanya. Saat ini, lahan kosong di daerah perkotaan sangat jarang ditemui. ruang untuk tempat tinggal, ruang untuk kelancaran lalu lintas kendaraan, dan tempat parkir sudah sangat minim. Bahkan, lahan untuk Ruang Terbuka Hijau (RTH) pun sudah tidak ada lagi. Lahan kosong yang terdapat di daerah perkotaan telah banyak dimanfaatkan oleh para urban sebagai lahan pemukiman, perdagangan, dan perindustrian yang legal maupun ilegal. Bangunan-bangunan yang didirikan untuk perdagangan maupun perindustrian umumnya dimiliki oleh warga pendatang. Selain itu, para urban yang tidak memiliki tempat tinggal biasanya menggunakan lahan kosong sebagai pemukiman liar mereka. hal ini menyebabkan semakin minimnya lahan kosong di daerah perkotaan.

2. Menambah polusi di daerah perkotaan. Masyarakat yang melakukan urbanisasi baik dengan tujuan mencari pekerjaan maupun untuk memperoleh pendidikan, umumnya memiliki kendaraan. Pertambahan kendaraan bermotor roda dua dan roda empat yang membanjiri kota yang terus menerus, menimbulkan berbagai polusi atau pemcemaran seperti polusi udara dan kebisingan atau polusi suara bagi telinga manusia. Ekologi di daerah kota tidak lagi terdapat keseimbangan yang dapat menjaga keharmonisan lingkungan perkotaan. 
Sebagian besar kota di Indonesia mengalami persoalan polusi sebagai akibat dari proses urbanisasi, baik oleh semakin banyaknya jumlah kendaraan maupun oleh industri-industri yang tumbuh.

3. Penyebab bencana alam. Para urban yang tidak memiliki pekerjaan dan tempat tinggal biasanya menggunakan lahan kosong di pusat kota maupun di daerah pinggiran Daerah Aliran Sungai (DAS) untuk mendirikan bangunan liar baik untuk pemukiman maupun lahan berdagang mereka. Hal ini tentunya akan membuat lingkungan tersebut yang seharusnya bermanfaat untuk menyerap air hujan justru menjadi penyebab terjadinya banjir. daerah aliran sungai sudah tidak bisa menampung air hujan lagi.

4. Pencemaran yang bersifat sosial dan ekonomi. Kepergian penduduk desa ke kota untuk mengadu nasib tidaklah menjadi masalah apabila masyarakat mempunyai keterampilan tertentu yang dibutuhkan di kota. Namun, kenyataanya banyak diantara mereka yang datang ke kota tanpa memiliki keterampilan kecuali bertani. Oleh karena itu, sulit bagi mereka untuk memperoleh pekerjaan yang layak. Mereka terpaksa bekerja sebagai buruh harian, penjaga malam, pembantu rumah tangga, tukang becak, masalah pedagang kaki lima dan pekerjaan lain yang sejenis. Hal ini akhitnya akan meningkatkan jumlah pengangguran di kota yang menimbulkan kemiskinan dan pada akhirnya untuk dapat memenuhi kebutuhan hidupnya, orangorang akan nekat melakukan tindak kejahatan seperti mencuri, merampok bahkan membunuh. Ada juga masyarakat yang gagal memperoleh pekerjaan sejenis itu menjadi tunakarya, tunawisma, dan tunasusila.

5. Penyebab kemacetan lalu lintas. Padatnya penduduk di kota menyebabkan kemacetan dimana-mana, ditambah lagi arus urbanisasi yang makin bertambah. Para urban yang tidak memiliki tempat tinggal maupun pekerjaan banyak mendirikan pemukiman liar di sekitar jalan, sehingga kota yang awalnya sudah macet bertambah macet. Selain itu tidak sedikit para urban memiliki kendaraan sehingga menambah volum kendaraan di setiap ruas jalan di kota.

6. Merusak tata kota. Pada negara berkembang, kota-kotanya tdiak siap dalam menyediakan perumahan yang layak bagi seluruh populasinya. Apalagi para migran tersebut kebanyakan adalah kaum miskin yang tidak mampu untuk membangun atau membeli perumahan yang layak bagi mereka sendiri. Akibatnya timbul perkampungan kumuh dan liar di tanah-tanah pemerintah.

\subsection{Dampak Urbanisasi Bagi Perkembangan Kota Di Indonesia}

Menurut Tjiptoherijanto (2007), meningkatnya proses urbanisasi tidak terlepas dari kebijaksanaan pembangunan perkotaan, khususnya pembangunan ekonomi yang dikembangkan oleh pemerintah. Sebagaimana diketahui peningkatan jumlah penduduk akan berkorelasi positif dengan meningkatnya urbanisasi di suatu wilayah. Ada kecenderungan bahwa aktivitas perekonomian akan terpusat pada suatu area yang memiliki tingkat konsentrasi penduduk yang cukup tinggi. Hubungan 
positif antara konsentrasi penduduk dengan aktivitas kegiatan ekonomi ini akan menyebabkan makin membesarnya area konsentrasi penduduk, sehingga menimbulkan apa yang dikenal dengan nama daerah perkotaan.

\section{Jakarta}

Karakteristik urbanisasi yang terjadi di DKI (Daerah Khusus Ibukota) Jakarta hampir sama dengan kota-kota besar di dunia, yaitu ditandai dengan meningkatnya jumlah penduduk kota yang terjadi setiap tahun. Kemudian dilanjutkan dengan pemusatan segala aktivitas masyarakat yang tertuju pada satu kawasan sehingga secara radikal merubah struktur keruangan kota. Perubahan tersebut terlihat pada pola perubahan pemanfaatan lahan yang diindikasikan oleh intensitas lahan terbangun, sebaran fasilitas perkotaan, sistem jaringan transportasi serta pola pergerakan ke pusat kota, juga perkembangan land use, perkembangan tingkat urbanisasi dan migrasi penduduk kota, dan selanjutnya perkembangan aktivitas ekonomi kota.

Metropolitan Jakarta memiliki laju perkembangan kota sangat tinggi dan kompleks. Gejala tersebut mulai terasa sejak akhir tahun 60-an hingga sekarang. Hingga kini urbanisasi di Jakarta telah membengkak lebih dari 10 juta jiwa dengan pertambahan penduduk relatif tinggi. Akibatnya telah terjadi kemacetan lalu lintas, pencemaran lingkungan, banjir, dan penggunaan lahan yang tak terkendali. Kondisi seperti ini telah menjadi fenomena keseharian bagi pertumbuhan Kota Jakarta.

Perkembangan pemanfaatan lahan di Jakarta mulai meningkat dengan dimulainya Repelita. Pada Pelita I dan II, pemerintah bertindak sebagai satu-satunya pemrakarsa pembangunan. Namun kemudian pada Pelita III peran swasta mulai nampak dan memiliki kemampuan untuk melakukan investasi pembangunan. Sebagai akibatnya, kawasan dengan kepadatan rendah yang awalnya diperuntukkan sebagai cachtment area (daerah tangkapan air) berubah menjadi lahan perumahan. Demikian pula dengan kawasan pinggiran Jakarta (perbatasan dengan Botabek), sudah berkembang pesat aktivitas-aktivitas perumahan dan industri. Perkembangan lebih lanjut tidak hanya di wilayah Kota Jakarta, melainkan menyebar sampai ke wilayah Bogor, Bekasi, Tangerang, dan Depok hingga kemudian ditetapkan sebagai wilayah perluasan Kota Jakarta yang disebut dengan Jabodetabek.

Dampak yang ditimbulkan proses urbanisasi bagi Kota Jakarta :

- Lahan terbagun vs lahan hijau/terbuka.

Perkembangan Kota Jakarta yang semakin meningkat menimbulkan beberapa permasalahan, terutama dalam hal kebutuan perumahan dan transportasi. Pembangunan perumahan baik oleh pemerintah maupun swasta berdampak pada meningkatnya intensitas lahan terbangun, bahkan lahan konservasi juga dijadikan sebagai perluasan permukiman kota. Intensitas lahan terbangun yang terus meningkat menyebabkan sulit dijumpainya lahan hijau/terbuka yang berfungsi sebagai ruang publik. Dapat dipastikan hampir seluruh lahan di DKI (Daerah Khusus Ibukota) Jakarta sudah terbangun baik untuk bangunan perumahan, kawasan perdagangan dan jasa, industri, perkantoran maupun bangunan lain.

- Sebaran failitas perkotaan.

Aktivitas perkotaan yang ada di Jakarta tidak terlepas dari fungsinya sebagai 
ibukota negara. Fungsi ini tidak hanya sebagai pusat pelayanan secara nasional tetapi juga interaksi antar negara. Disamping sebagai pusat pemerintahan, pusat industri dan perdagangan, pusat aktivitas pelayanan jasa, Jakarta juga sebagai pintu masuk dan keluarnya transportasi internasional yang mobilitasnya cukup tinggi. Karena sifatnya yang demikian, maka muncul berbagai kawasan perdagangan, kawasan rekreasi, serta didukung oleh fasilitas perekonomian.

Efek yang timbul akibat pemanfaatan ruang yang berkaitan dengan persebaran fasilitas kota, cenderung mengindikasikan adanya pemusatan aktivitas di beberapa kawasan. Dampak bangkitan yang muncul adalah terakumulasinya aktivitas transportasi ke pusat kota yang semakin padat. Fenomena ini adalah bukti nyata tidak terkendalinya aktivitas transportasi kota dengan baik.

- Jaringan transportasi dan pola pergerakan ke pusat kota.

Jaringan transportasi dan pola pergerakan ke pusat kota Jakarta dari kawasan suburban dan atau kota-kota di luar Jakarta memicu adanya penyesuaian, perbaikan, dan penambahan jalan dan moda angkutan baru. Data tahun 1998/1999 mencatat bahwa pada jam-jam puncak setidaknya terdapat lebih dari 40.000 kendaraan yang melintas di berbagai ruas jalan di Jakarta. Selain itu, besarnya mobilitas penduduk ke tempat kerja menuju Jakarta yang berasal dari Bodetabek dan dalam Jakarta sendiri mencapai angka $62,5 \%$. Pola pergerakan seperti ini mengakibatkan terbentuknya suatu pola ulang alik atau commuter antara DKI Jakarta dan Bodetabek. Faktor utama penyebab kemacetan tersebut adalah adanya bangkitan penduduk di wilayah Botabek ke wilayah DKI Jakarta. Kebijakan penambahan dan pelebaran badan jalan hanyalah salah satu terapi masalah transportasi, sebab apabila mobilitas penduduk tidak dikendalikan dengan baik tanpa melihat aspek keruangannya, maka kemacetan selamanya akan tetap muncul. Oleh karena itu pelebaran badan jalan sebagai langkah antisipasi, tidak akan begitu saja dapat mengatasi persoalan transportasi. Penekanan penanganan sistem transportasi harus diiringi dengan pemerataan pusat-pusat fasilitas publik di berbagai kawasan sub urban. Dengan demikian pola pergerakan penduduk yang selama ini terpusat di Jakarta, berangsur-angsur mengarah dan menyebar ke kawasan sub urban.

- Perkembangan land use.

Perkembangan Kota Jakarta mulai menunjukkan percepatan pembangunan sejak awal Repelita III sejalan dengan keberhasilan pembangunan di bidang ekonomi. Lalu perkembangan tersebut semakin masif, dimana terjadi pembangunan dan pengembangan seperti permukiman/perumahan secara intensif dan ekstensif yang dilakukan oleh pemerintah maupun pihak swasta. Hal ini berdampak pada perubahan struktur tata ruang perkotaan DKI Jakarta.

Pertumbuhan ekonomi yang cukup cepat di Jakarta mempengaruhi intensitas penggunaan lahan untuk aktivitas bangkitan berupa industri, perdagangan dan jasa. Akibatnya harga lahan semakin mahal, bahkan tibul kondisi kelangkaan lahan di pusat kota Jakarta. Sehingga yang terjadi adalah penyebaran minat investasi ke 
wilayah pinggiran Jakarta yang dibarengi dengan sistem aksesibilitas yang semakin baik. Perkembangan yang dimulai dari barat kota satelit Bumi Serpong Damai, kemudian Lippo Karawaci, Kota Legenda, memanjang hingga Balaraja Industrial Esate, merupakan bukti nyata adanya pergeseran minat investasi itu.

Pada saat ini perkembangan struktur ruang Kota Jakarta masih diarahkan pada pengembangan poros barat dan timur. Akan tetapi karena tekanan pembangunan yang cukup besar maka daerah selatan pun yang sebelumnya adalah kawasan tangkapan air, berangsur-angsur mulai berdiri bangunan-bangunan permukiman Dampak yang timbul adalah terjadinya sprawling area yang menciptakan wilayah tidak saling terikat secara fungsi antara satu dengan lainnya.

- Pemukiman kumuh.

Seiring dengan meluasnya urbanisasi, tumbuh subur kantung-kantung pemukiman kumuh (slum area) dan kampong-kampung di tengah kota yang serba menyesakkan dan liar. Semakin banyak penduduk kota yang tinggal berhimpit-himpit di berbagai pusat pemukiman yang sebenarnya tidak pantas dihuni oleh manusia. Namun pemukiman-pemukiman ini terus saja mendapat tambahan para pemukim tetap dengan jumlah dua kali lipat setiap lima hingga sepuluh tahun. Pemukiman-pemukiman kumuh di Jakarta dapat dilihat di daerah pinggiran sungai, di bawah jembatan, daerah pinggiran rel, pusat perdagangan, dan sebagainya.

- Permasalahan lingkungan.

Pengalihan fungsi lahan secara berlebihan menimbulkan ketidak seimbangan alam akibat pembangunan yang dilakukan tanpa perencanaan terpadu. Pengelolaan sarana dan prasarana kota yang tidak baik juga turut menyumbang terhadap semakin tingginya angka kerusakan alam di Kota Jakarta. Banjir, tanah longsor, polusi udara, tanah, air dan suara merupakan permasalahan lingkungan yang sangat mudah dijumpai di Kota Jakarta.

- Pengangguran dan kemiskinan.

Meledaknya jumlah pencari tenaga kerja baik di sektor formal maupun sektor informal diakibatkan oleh tingkat penawaran tenaga kerja jauh melebihi tingkat permintaan yang ada, sehingga mengakibatkan tingginya angka pengangguran dan semi pengangguran di daerah perkotaan. Terbatasnya pendidikan, kemampuan dan ketrampilan yang dimiliki juga menjadi penghalan bagi pencari kerja untuk mendapatkan pekerjaan. Tingginya angka pengangguran akhirnya menyumbang pada semakin besarnya komposisi orang-orang atau masyarakat miskin di perkotaan sebagaimana yang terlihat di Kota Jakarta.

- Kriminalitas.

Tekanan untuk bertahan hidup (survive) misalnya, akan mendorong manusia bertindak apapun, termasuk tindakan kriminal. Hal ini pulalah yang menjadi penyebab mengapa angka kriminalitas di Jakarta semakin hari semakin meningkat. Himpitan akan tuntutan hidup yang tidak dapat dipenuhi membuat sebagian individu memilih bertahan dengan cara tersebut. Tindakan kriminal seperti mencuri, merampok, membunuh, dan sebagainya menjadi pemandangan yang tidak asing 
lagi dalam kehidupan perkotaan di Jakarta.

\section{PENUTUP}

\section{Kesimpulan}

Masalah urbanisasi yang dihadapi Indonesia saat ini yaitu pertumbuhan konsentrasi penduduk yang tinggi. Lebih buruk lagi, hal ini tidak diikuti dengan kecepatan yang sebanding dengan perkembangan industrialisasi. Masalah ini akhirnya menimbulkan fenomena yaitu urbanisasi berlebih. Adanya urbanisasi yang berlebih ini telah menimbulkan berbagai masalah di Indonesia. Tidak hanya menimbulkan masalah di kota yang dituju namun juga menimbulkan masalah di desa yang ditinggalkan. Masalah yang terjadi kota antara lain yaitu meningkatnya angka kemiskinan sehingga pemukiman kumuhnya juga meningkat, peningkatan urban crime dan masih banyak masalah lain. Di desa juga akan timbul masalah diantaranya yakni berkurangnya sumber daya manusia karena penduduknya telah pergi ke kota, desa akhirnya tidak mengalami perkembangan yang nyata.

Kondisi perkotaan yang semakin tidak terkendali akibat adanya urbanisasi yang berlebih, telah menimbulkan berbagai masalah baru seperti meningkatnya kriminalitas akibat kemiskinan, pengangguran besar-besaran, bertambahnya pemukiman kumuh, dan lain sebagainya. Oleh karena itu, urbanisasi akan dlihat sebagai faktor penentu bagai sebuah kota dapat berkembang baik secara fisik, maupun secara sosial. Dengan begitu, bentuk atau pengertian dari urbanisasi itu dapat dilihat dengan lebih jelas juga akibat/dampak yang ditimbulkannya terhadap kehidupan di kota.
Dampak urbanisasi bagi perkembangan kota denga melihat perkembangan Kota Jakarta yaitu :

1. Secara fisik

- Lahan terbangun vs lahan hijau/terbuka

Dapat dipastikan hampir seluruh lahan di DKI Jakarta sudah terbangun baik untuk bangunan perumahan, kawasan perdagangan dan jasa, industri, perkantoran maupun bangunan lain. Intensitas lahan terbangun yang terus meningkat menyebabkan sulit dijumpainya lahan hijau/terbuka yang berfungsi sebagai ruang publik

- Sebaran fasilitas perkotaan

Disamping sebagai pusat pemerintahan, pusat industri dan perdagangan, pusat aktivitas pelayanan jasa, Jakarta juga sebagai pintu masuk dan keluarnya transportasi internasional yang mobilitasnya cukup tinggi. Karena sifatnya yang demikian, maka muncul berbagai kawasan perdagangan, kawasan rekreasi, serta didukung oleh fasilitas perekonomian.

- Jaringan transportasi dan pola pergerakan ke pusat kota

Jaringan transportasi dan pola pergerakan ke pusat kota Jakarta dari kawasan suburban dan atau kota-kota di luar Jakarta memicu adanya penyesuaian, perbaikan, dan penambahan jalan dan moda angkutan baru.

- Perkembangan land use Pembangunan dan pengembangan permukiman atau perumahan secara intensif dan ekstensif yang 
dilakukan oleh pemerintah maupun pihak swasta yang berdampak pada perubahan struktur tata ruang perkotaan DKI Jakarta.

- Permasalahan lingkungan

Menurunnya daya dukung dan kualitas lingkungan sebagai akibat dari pembangunan yang tidak terencana serta pengaturan sarana dan prasarana kota yang semrawut menimbulkan permasalahan lingkungan yang semakin parah seperti banjir, tanah longsor, polusi udara, tanah, air dan udara.

- Pemukiman kumuh

Semakin banyak penduduk kota yang tinggal berhimpit-himpit di berbagai pusat pemukiman dan terus bertambahnya para pemukim tetap dengan jumlah dua kali lipat setiap lima hingga sepuluh tahun.

2. Secara sosial

- Pengangguran dan kemiskinan Meledaknya jumlah pencari tenaga kerja baik di sektor formal maupun sektor informal diakibatkan oleh tingkat penawaran tenaga kerja jauh melebihi tingkat permintaan yang ada, sehingga mengakibatkan tingginya angka pengangguran dan semi pengangguran di daerah perkotaan. Terbatasnya pendidikan, kemampuan dan ketrampilan yang dimiliki juga menjadi penghalan bagi pencari kerja untuk mendapatkan pekerjaan.

- Kriminalitas

Tekanan untuk bertahan hidup (survive) misalnya, akan mendorong manusia bertindak apapun, termasuk tindakan kriminal. Hal ini pulalah yang menjadi penyebab mengapa angka kriminalitas di Jakarta semakin hari semakin meningkat.

\section{DAFTAR PUSTAKA}

\section{Buku}

Abbas, Ardi, Diktat Untuk Kalangan Sendiri : Sosiologi Perkotaan, Padang : Jurusan Sosiologi Universitas Andalas, Padang, 2002.

Ardiyansyah, Adi, Dampak Kemiskinan Kota Terhadap Perumahan dan Pemukiman Di kota-kota Besar di Indonesia (online), 2009, http://file.upi.edu, Diakses 7 Desember 2011.

Daldjoeni, N., Seluk Beluk Masyarakat Kota Pusparagam Sosiologi Kota, Penerbit Alumni, Bandung, 1978.

Gmelch, George., Watter P Zenner (Editors), Urban Life Reading in Urban Anthropology, St. Martin's Press, New York, 1980.

Rahardjo, Perkembangan Kota dan Permasalahannya, PT Bina Aksara Jakarta, 1993.

Syaukat, Syarifah F., Kota dan Perkembangannya di Indonesia, Makalah, Tidak dipublikasikan, 2005.

Todaro, Michael P, Pembangunan Ekonomi Di Dunia Ketiga, Erlangga, Jakarta, 1983.

Tjiptoherijanto, Prijono,. Urbanisasi, Mobilitas dan Perkembangan Perkotaan di Indonesia, 2007, http://robbyalexandersirait.wordpress. com, diakses pada 8 Desember 2011. 